\title{
Profilaktikus sztentek alkalmazása az endoszkópos retrográd cholangiopancreatographiát követő pancreatitis megelözésében
}

\author{
Dubravcsik Zsolt dr. ${ }^{1}$. Hritz István dr. ${ }^{2}$ \\ Szepes Attila dr. ${ }^{1}$. Madácsy László dr. ${ }^{3}$ \\ ${ }^{1}$ Bács-Kiskun Megyei Kórház, Belgyógyászat, Gasztroenterológia, Kecskemét \\ ${ }^{2}$ Semmelweis Egyetem, Általános Orvostudományi Kar, \\ I. Sebészeti Klinika, Invazív Endoszkópos Centrum, Budapest \\ ${ }^{3}$ Endo-Kapszula Magánorvosi Centrum, Székesfehérvár
}

\begin{abstract}
Bevezetés: Az endoszkópos retrográd cholangiopancreatographiát (ERCP) követő pancreatitis (PEP) incidenciája a magas kockázatú betegcsoportban 14,7\%.

Célkitüzés: A munkacsoportunk által szerzett tapasztalatok elemzése.

Módszerek: A profilaktikus pancreassztentes (PPS), magas kockázatú betegek adatait tartalmazó prospektív adatbázisunkat elemeztük retrospektív módon. Az adatokat a PEP-incidencia és a súlyosság tekintetében összehasonlítottuk a korábbi, hasonlóan magas kockázatú, sztent nélküli beteganyagunkkal, illetve a sztenteléssel kapcsolatos szövődményeket és a különböző sztenttípusokat is elemeztük. A Cotton-kritériumok szerint értékeltük a PEP-t.

Eredmények: A 317, magas kockázatú betegből 288 esetben $(90,9 \%)$ volt sikeres a PPS-implantáció. A sztent nélküli kontrollcsoportba 121, magas kockázatú beteget választottunk be. A sikeresen sztentelt betegekben a PEP incidenciája 10,0\% volt. Ez és a PEP súlyossága (enyhe: 8,3\%, középsúlyos: 1,4\%, súlyos: 0,3\%) is szignifikánsan alacsonyabb volt a PPS nélküli beteganyaghoz (PEP: 31,4\%, enyhe: 15,7\%, középsúlyos: 10,7\%, súlyos: 5,0\%) és a sikertelenül sztentelt betegekhez (PEP: 41,3\%, enyhe: 24,1\%, középsúlyos: 13,8\%, súlyos: 3,4\%) képest. Az utóbbi két csoport közötti különbség nem volt szignifikáns. A sztenttel kapcsolatos szövődmények közül a leggyakrabban a korai sztentkicsúszást $(5 / 288$ beteg, 1,74\%) és a proximalis sztentmigrációt (3/288 beteg, 1,04\%) észleltük. A sztenttípusok közül a legkedvezőbb mellékhatás-profilúnak a Freeman-típusú, belső füllel és külső „pigtail” véggel ellátott sztenteket találtuk.

Következtetés: A profilaktikus pancreassztentelés hatékonyan csökkenti a PEP incidenciáját, és a súlyosságát az enyhébb esetek felé tolja el. Alkalmazása viszonylag egyszerú, azonban ismerni kell használatának megfelelő technikáját, időben történő eltávolításának és a szövődmények felismerésének fontosságát. Eredményeink és a nemzetközi ajánlások alapján magas PEP-rizikójú betegekben a PPS rutinszerű alkalmazása minden ERCP-laborban ajánlott.
\end{abstract}

Orv Hetil. 2021; 162(1): 31-38.

Kulcsszavak: profilaktikus pancreassztent, post-ERCP-pancreatitis, szövődmény

\section{Prophylactic stents in the prevention of pancreatitis following endoscopic retrograde cholangiopancreatography}

Introduction: The most frequent complication of endoscopic retrograde cholangiopancreatography (ERCP) is postERCP pancreatitis (PEP). Its incidence in the high-risk patient population is $14.7 \%$.

Objective: To analyze 10 years experiences of our working group.

Methods: We retrospectively analyzed our prospective database of high-risk patients treated with prophylactic pancreatic stents (PPS) including the period between 2009 and 2014. We compared PEP incidence and severity findings with our historical data of pre-PPS period of similarly high-risk patients (no-stent group), furthermore analyzed the complications of PPS insertion and different stent types. PEP was defined and categorized according to the Cotton criteria. 
Results: In 317 high-risk patients, PPS implantation was successful in 288 cases (90.9\%). The no-stent group comprised of 121 patients. Incidence and the severity of PEP in the successfully stented group (all: $10.0 \%$; mild: $8.3 \%$, moderate: $1.4 \%$, severe: $0.3 \%$ ) were significantly lower compared to the no-stent group (all: $31.4 \%$; mild: $15.7 \%$, moderate: $10.7 \%$, severe: $5.0 \%$ ) and the unsuccessfully stented group (all: $41.3 \%$; mild: $24.1 \%$, moderate: $13.8 \%$, severe: $3.4 \%)$. The difference between the latter two groups was not significant. Only early dislodgment $(5 / 288$ patients, $1.74 \%)$ and proximal migration $(3 / 288$ patients, $1.04 \%)$ were observed as stent-related complications. Freeman type (single inner flange, outer pigtail end) stent was the best based on the complication profile.

Conclusion: Prophylactic pancreatic stenting effectively lowers the incidence and severity of PEP. We should recognize the proper technic of its application and the importance of proper timing of its extraction and identification of complications. Utilization of PPSs in high-risk patients is strongly recommended in every ERCP center.

Keywords: prophylactic pancreatic stent, post-ERCP pancreatitis, complication

Dubravcsik Zs, Hritz I, Szepes A, Madácsy L. [Prophylactic stents in the prevention of pancreatitis following endoscopic retrograde cholangiopancreatography]. Orv Hetil. 2021; 162(1): 31-38.

(Beérkezett: 2020. június 1.; elfogadva: 2020. július 20.)

\section{Rövidítések}

BFS = belső füles sztent; BNS = belső fül nélküli sztent; ERCP = endoszkópos retrográd cholangiopancreatographia; ESGE = (European Society of Gastrointestinal Endoscopy) Európai Gastrointestinalis Endoszkópos Társaság; FS = Freeman-típusú sztent; NSAID = (non-steroidal anti-inflammatory drug) nemszteroid gyulladáscsökkentő szer; OSD = Oddi-sphincterdyskinesis; PEP = post-ERCP-pancreatitis; PPS = profilaktikus pancreassztent; taj = társadalombiztosítási azonosító jel

Az endoszkópos diagnosztika és intervenció fejlódése ellenére az endoszkópos retrográd cholangiopancreatographia (ERCP) továbbra is az egyik legösszetettebb, a legnagyobb szakmai és eszközös felkészültséget igénylő, operatív endoszkópos módszer. Szövődményrátája is ennek megfelelően viszonylag magas. Ezek közül a leggyakoribb, legrettegettebb és széles körben ismert komplikáció a pancreatitis (post-ERCP-pancreatitis - PEP), melynek incidenciája egy közelmúltban megjelent, randomizált vizsgálatok elemzéséből készült összefoglaló tanulmány szerint átlagosan 9,7\%, magas kockázatú betegek esetén azonban átlagosan 14,7\% [1]. Napjainkra számos beteg- és beavatkozásfüggő rizikófaktor vált ismertté, melyek a PEP előfordulását jelentős mértékben emelhetik, ugyanis az általuk hordozott kockázat összeadódik. Az Európai Gastrointestinalis Endoszkópos Társaság (European Society of Gastrointestinal Endoscopy - ESGE) által kiadott ajánlás összefoglalja ezeket a kockázati tényezőket, melyeket az 1. táblázatban ismertetünk [2]. Freeman és mtsai akár tízszeres kockázatot meghaladó esélyhányadost közöltek sokszor idézett munkájukban [3]. A PEP előfordulása 42\%-os volt azon fiatal nőbetegekben, akiknél Oddi-sphincter-dyskinesisről (OSD) volt szó, szérumbilirubinjuk normális, az epeúti kanülálás pedig nehéz volt. A korábban előreláthatatlannak és elkerülhetetlennek hitt PEP-előfordulási esély manapság - a rizikótényezóket figyelembe véve - nagy pontossággal előre megbecsülhető.
A PEP pontos patomechanizmusa nem ismert, jóllehet mechanikus, hidrosztatikus, kémiai/enzimatikus, allergiás, termikus és mikrobiológiai faktorok szerepét is feltételezték. A legtöbb tanulmány az Oddi-sphincter vagy a pancreaticus sphincter spazmusát és traumáját/ sérülését feltételezi, mely a pancreasvezeték peripapillaris szakaszának és a Vater-papillának az ödémáját és következményes pancreasnedv-kiáramlási akadályozottságot okoz. Mindenesetre a kiváltó októl és az iniciáló lépésektől függetlenül, ha a folyamat egyszer beindul, akkor a gyulladásos kaszkád az akut pancreatitis egyéb formáihoz hasonlatos. A tripszin korai, intraacinaris aktivációját intrapancreaticus, majd extrapancreaticus gyulladásos fázis követi $[4,5]$.

Számos tanulmányban próbálták ezt a kaszkádot befolyásolni, olyan gyógyszert vagy endoszkópos módszert kerestek, mellyel a PEP megelőzhető vagy kialakulásának valószínúsége és súlyossága csökkenthető. Az elmúlt 20 évben megjelent prospektív, randomizált tanulmányokban számos gyógyszerrel próbálták a gyulladásos láncreakció valamelyik pontját leállítani, ezek azonban többnyire nem váltották be a hozzájuk füzött reményeket. Az ESGE kizárólag a nemszteroid gyulladáscsökkentő szer (non-steroidal anti-inflammatory drug - NSAID) közvetlenül ERCP előtti alkalmazását javasolja - rectalisan 100 mg diklofenák vagy indometacin - kúp formájában [2].

Az endoszkópos módszerek közül a megfelelő betegszelekció és a lehetőség szerinti atraumatikus, 5-10 percen belüli szelektív kanülálási technikán kívül a profilaktikus pancreassztentek (PPS) alkalmazása indokolt a magas kockázatú betegekben. PPS alkalmazásával ebben a betegcsoportban a PEP kialakulásának kockázata a felére csökken, ami 12\%-os abszolút rizikócsökkenést (intention-to-treat analízis) jelent. Egy PEP-epizód megelőzéséhez 8 beteget kell PPS-sel kezelni (number needed to treat) [6]. Korábbi tanulmányunkban, ahol a PPS-implantációban részesített betegeink prospektív 
adatbázisát elemeztük, kimutattuk, hogy a PPS alkalmazása jelentősen csökkenti az egyes PEP-rizikófaktorok által hordozott kockázatot, továbbá PPS alkalmazása mellett az egyedüli szignifikáns tényező az OSD; illetve azon betegek, akikben PEP alakult ki, szignifikánsan több betegfüggő rizikófaktorral bírnak, mint azok, akikben nem [7].

Jelen retrospektív tanulmányunkban a PPS alkalmazásával szerzett tapasztalatainkat elemezzük. Célkitúzésünk annak megállapítása, hogy magas kockázatú betegcsoportunkban a PEP kialakulását a PPS alkalmazása hogyan befolyásolja, illetve a kis kaliberú pancreassztentek alkalmazása kapcsán milyen szövődményeket észlelünk, továbbá a különböző kialakítású sztentek között észlelhető-e különbség a hatékonyság és a szövődményráta tekintetében.

\section{Módszerek}

Két, nagy forgalmú megyei kórház prospektív, a korábban említett PPS PEP-rizikófaktorokra gyakorolt hatásának vizsgálatára készített adatbázisát elemeztük újra retrospektív módon, a célkitűzéseinkben megfogalmazott szempontok alapján. Az adatbázis a 2009 és 2014 között ERCP-vizsgálaton átesett betegek adatait tartalmazza, így a 2010-ben megjelent ESGE-ajánlásban leírt rizikófaktorokat foglalja magában (1. táblázat) [8].

Az ajánlás alapján magas kockázatúnak tartható, így PPS-implantáció indokolt azon ERCP-vizsgálatra kerülő betegeknél, akiknél a rizikófakorok közül 2-nél több jelen van (ezek közül legalább 1 biztos rizikófaktor).

A sztentelt betegek adatait összehasonlítottuk a 2000 és 2004 között készített ERCP-adatbázisunk hasonlóan magas kockázatú betegpopulációjának adataival, ahol PPS alkalmazása nem történt, ez ugyanis abban az időben nem volt a rutin-ERCP része („sztent nélküli retrospektív kohorsz" csoport).

Adatbázisunk az említett rizikófaktorokon kívül a következő adatokat tartalmazza: betegazonosító (taj szám); demográfiai adatok (nem, születési dátum, az ERCP dátuma, életkor az ERCP idején); a beteg- és beavatkozásfüggő rizikófaktorok és az összes rizikófaktor száma; a PPS típusa (hossz, átmérő, kivitel/típus); megkísérelt, de sikertelen PPS-implantáció; a PPS-kivétel ideje; PEP (megjelenés, illetve súlyosság); a beavatkozás utáni hasi panasz előfordulása, illetve a vizsgálat utáni esti (6-8 órás) és másnap reggeli (16-24 órás) szérumamilázszint; egyéb szövődmények.

A betegek ellátásához $5 \mathrm{Fr}, 3-5 \mathrm{~cm}$ hosszú PPS-eket használtunk, melyek között egyenes, belső fül nélküli, csak kettős külső füllel bíró (belső fül nélküli sztent BNS), továbbá egyenes, kettős belső és kettős külső füllel is bíró (belső füles sztent - BFS), valamint egy belső füllel és külső „pigtail” (malacfarok-szerúen) hajlított véggel rendelkező (Freeman-típusú sztent - FS) sztenteket használtunk. A pancreassztenteket legkésőbb 1 héten belül gyomortükrözés során hurokkal vagy idegentest-
1. táblázat |A post-ERCP-pancreatitis független rizikótényezői a 2020. és a 2010. évi ESGE-ajánlás alapján

Esélyhányados

(OR - odds ratio)

ESGE 2020 ESGE 2010

[2]

[8]

Betegfüggő rizikófaktorok

Biztos rizikófaktorok

Oddi-sphincter dyskinesis gyanúja

2,04-4,37 4,09

Női nem

$1,4-2,23 \quad 2,23$

Előző pancreatitis

2,0-2,9 2,46

Előző PEP

$3,23-8,7$

Valószinü rizikófaktorok

Fiatalabb életkor (<60 év)

$1,59-2,87 \quad 1,09-2,87$

Nem tág extrahepaticus epeutak

$3,8 \quad$ NA

A krónikus pancreatitis hiánya

$1,87 \quad 1,87$

Normális szérumbilirubin

$1,89 \quad 1,89$

Végstádiumú veseelégtelenség

1,7

Beavatkozásfüggő rizikófaktorok

Biztos rizikófaktorok

Nehéz kanülálás

1,76-14,9

Pancreasba vezetődrót jut $>1 \times$

2,1-2,77

A pancreasvezeték töltése

$1,58-2,72$

2,2

'Precut' sphincterotomia

Valószinu" rizikófaktorok

'Precut' sphincterotomia

$2,11-3,1$

Pancreaticus sphincterotomia

1,23-3,07

3,07

Az intakt sphincter ballondilatációja

4,51

4,51

Sikertelen epeúti kőmentesítés

4,51

3,35

Intraductalis ultrahangvizsgálat

2,41

Többszörös sikertelen kanülálási kísérlet

$2,4-3,41$

Amelyik rizikófaktor nem szerepel az adott évi ajánlásban, ott az esélyhányados értékét kihúztuk (-).

ERCP = endoszkópos retrográd cholangiopancreatographia; ESGE = Európai Gastrointestinalis Endoszkópos Társaság; NA = nincs adat; $\mathrm{OR}=$ esélyhányados; PEP = ERCP-t követő pancreatitis

fogóval megfogva a betegekből rutinszerúen eltávolítottuk, ha addig spontán nem távoztak, és amennyiben a beteg az előjegyzett vizsgálatra megjelent (1. ábra).

A betegeket legalább az ERCP másnapjáig a hazai általános gyakorlatnak megfelelően osztályunkon egynapos megfigyelésre és kezelésre hospitalizáltuk. Az ERCP utáni 8-12 órában koplalás mellett minden beteg rutinszerüen parenteralis folyadékpótlást (2000-3000 ml Ringer-laktát-infúziót) kapott. NSAID-kúpot PEP-profilaxisra ebben a beteganyagban nem alkalmaztunk. Szükség esetén fájdalomcsillapítót és görcsoldót kaptak a betegek, valamint a vizsgálat után 6-8 (aznap este), valamint 16-24 órával (másnap reggel) vérképet és szérumamilázszintet néztünk laboratóriumi vizsgálattal. A hos- 


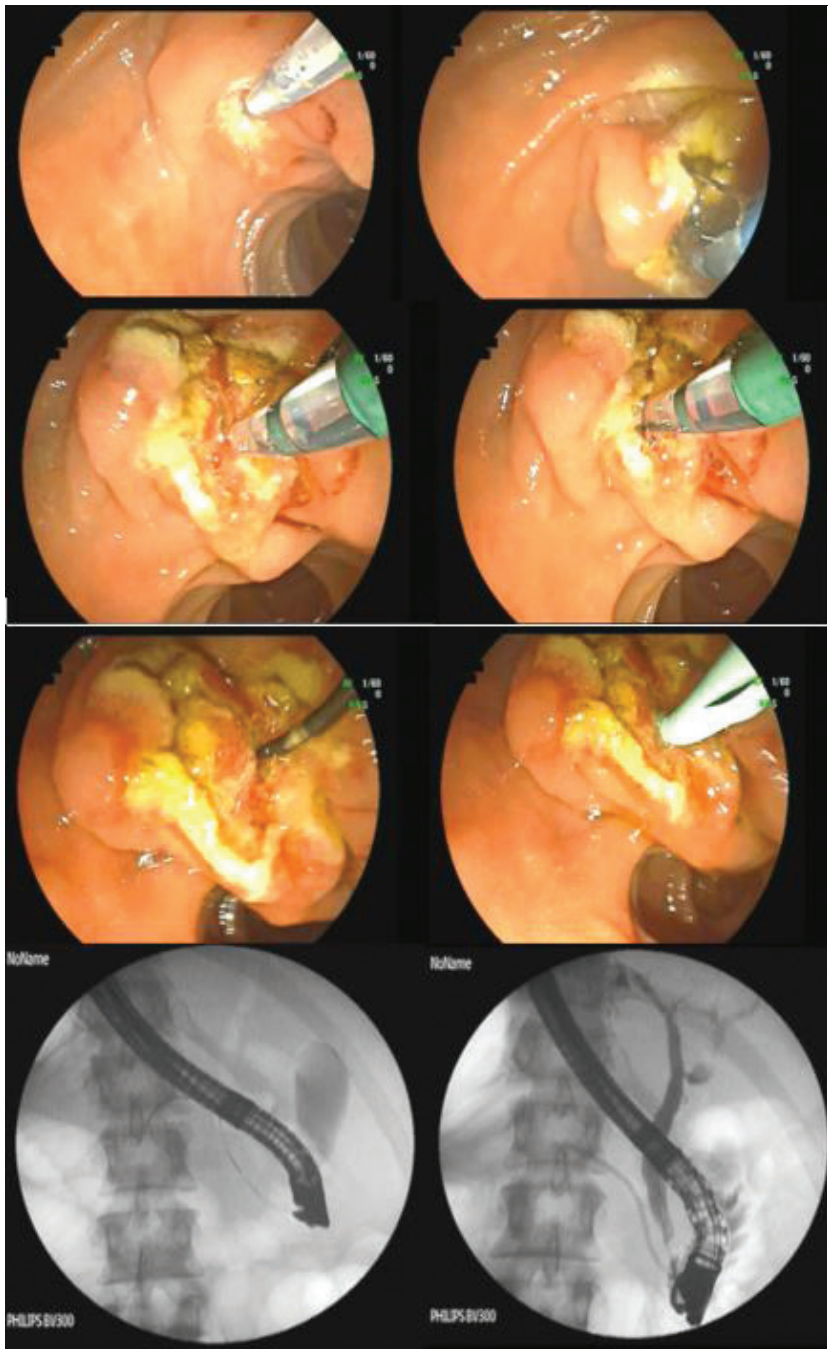

1. ábra

PPS sikeres behelyezése elhúzódó epeúti kanülálást, túpapillotomiát, majd hagyományos papillotomiát követően egy biliaris pancreatitises és papillastenosisos betegben. Típusos esetben pancreassztent behelyezése az epeúti intervenciót követően történik olyan módon, hogy kanülotomon át vezetődróttal szelektíven felkeressük a Wirsung-vezetéket, majd kontraszt adása nélkül, a drótot a pancreas test-farok határon tartva, annak segítségével egy $5 \mathrm{Fr}$-es, $3-5 \mathrm{~cm}$-es, belső füllel rendelkező profilaktikus pancreassztentet juttatunk a vezetékbe

PPS $=$ profilaktikus pancreassztent

pitalizációt a tünetmentességig vagy a PEP lezajlásáig tartottuk fenn, a szövődményes eseteket pedig 3 hónap múlva ambulanter kontrolláltuk. A PEP ellátását a szakmai szabályok szerint végeztük.

A PEP kialakulását és súlyosságát a Cotton és mtsai által közölt konszenzusajánlás irányelvei alapján definiáltuk [9]. A PEP definíciója: pancreatitisnek megfelelő hasi fájdalom, mely az ERCP-t követő 24 órával a szérumamiláznak a normálérték felső határát legalább $3 \times$-osan meghaladó emelkedésével jár együtt, és a beteg nem tervezett hospitalizációját vagy kórházi tartózkodásának legalább 2 nappal történő meghosszabbítását okozza. A kórházi tartózkodás ideje alapján a pancreatitist enyhe, középsúlyos és súlyos csoportokra osztjuk. A PEP enyhe esetben 2-3 nappal, középsúlyos esetben 4-10 nappal, végül súlyos esetben több mint 10 nappal nyújtja meg a kórházi tartózkodást. Súlyos PEP-nek számít, ha a pancreatitisnek szövődménye alakul ki (például vérzés, necrosis, folyadékgyülem: pseudocysta, 'walled-off' [demarkált/körülírt] pancreasnecrosis), vagy valamilyen intervenció (például drenázs vagy mútét) válik szükségessé.

A sztentekkel kapcsolatban fellépő egyéb szövődményeket is regisztráltuk, az irodalomban fellelhetőkre is figyelmet fordítva (korai kicsúszás, proximalis migráció, pancreasvezeték-perforáció, ductalis és parenchymalis eltérések, sztentfragmentáció a pancreasvezetéken belül, a PPS kivétele által indukált pancreatitis).

A szokásos statisztikai módszereket alkalmaztuk az adatok elemzéséhez (átlag, standard eltérés, kétmintás tpróba, khi-négyzet-próba, Fisher-teszt). A p $<0,05$ értéket tekintettük szignifikánsnak.

\section{Eredmények}

\section{A PEP-re vonatkozó eredmények}

Az adatbázis elemzése során látható volt, hogy 2462 ERCP-vizsgálatból 317 beteg esetében kíséreltünk meg PPS-implantációt a magas PEP-kockázat miatt (12,9\%). Ezek közül 288 esetben $(90,9 \%)$ volt sikeres a sztentelés („sikeres sztent” csoport), 29 esetben (9,1\%) azonban

2. táblázat |A vizsgálati csoportok post-ERCP-pancreatitis-kockázati értékei és az azok közötti szignifikanciaértékek

\begin{tabular}{lccc}
\hline & Sikeres sztent & Sikertelen sztent & Sztent nélküli \\
\hline Kor (év) & $60,97 \pm 16,51$ & $64,21 \pm 16,89$ & $60,86 \pm 11,73$ \\
$\begin{array}{l}\text { Összesített } \\
\text { rizikófaktorok }\end{array}$ & $4,86 \pm 1,47$ & $5,38 \pm 1,14$ & $5,13 \pm 1,25$ \\
$\begin{array}{l}\text { Betegfüggő } \\
\text { rizikófaktorok }\end{array}$ & $3,22 \pm 1,27$ & $3,34 \pm 1,23$ & $3,45 \pm 0,99$ \\
$\begin{array}{l}\text { Beavatkozásfüggő } \\
\text { rizikófaktorok }\end{array}$ & $1,64 \pm 0,97$ & $2,03 \pm 0,82$ & $1,68 \pm 1,11$ \\
\hline
\end{tabular}

Az adatok az egyes vizsgálati csoportok átlagát mutatják a standard eltéréssel $( \pm$ SD).

\begin{tabular}{lccc}
\hline Szignifikancia (p) & $\begin{array}{c}\text { Sikeres vs. } \\
\text { sikertelen }\end{array}$ & $\begin{array}{c}\text { Sikeres vs. } \\
\text { sztent nélküli }\end{array}$ & $\begin{array}{c}\text { Sikertelen vs. } \\
\text { sztent nélküli }\end{array}$ \\
\hline $\begin{array}{l}\text { Kor (év) } \\
\text { Összesített } \\
\text { rizikófaktorok }\end{array}$ & 0,32 & 0,95 & 0,21 \\
$\begin{array}{l}\text { Betegfüggó } \\
\text { rizikófaktorok }\end{array}$ & 0,61 & 0,07 & 0,33 \\
$\begin{array}{l}\text { Beavatkozásfüggó } \\
\text { rizikófaktorok }\end{array}$ & 0,03 & 0,07 & 0,61 \\
\hline
\end{tabular}

Az egyes vizsgálati csoportok között az életkorban és a rizikófaktorokban észlelt különbségek statisztikailag nem szignifikánsak.

ERCP = endoszkópos retrográd cholangiopancreatographia; $\mathrm{SD}=$ standard deviáció 


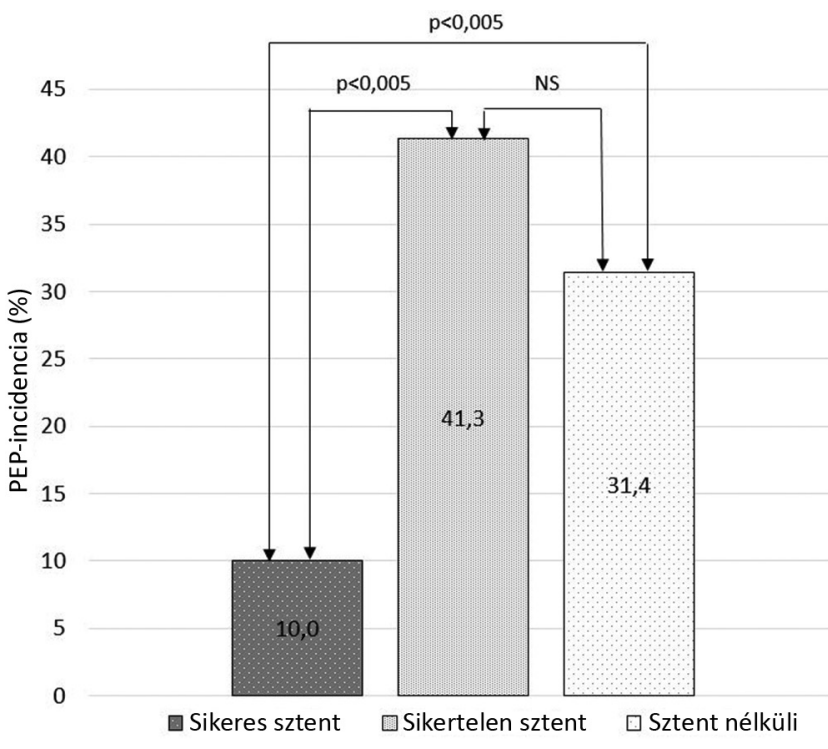

2. ábra $\mid$ A post-ERCP-pancreatitis incidenciája a különböző csoportokban. A magas PEP-rizikójú betegcsoportban a sikeres PPS-behelyezés jelentôsen és szignifikánsan csökkentette az összes PEP-szövődmény előfordulási gyakoriságát

ERCP = endoszkópos retrográd cholangiopancreatographia; $\mathrm{NS}=$ nem szignifikáns; PEP = ERCP-t követő pancreatitis PPS $=$ profilaktikus pancreassztent

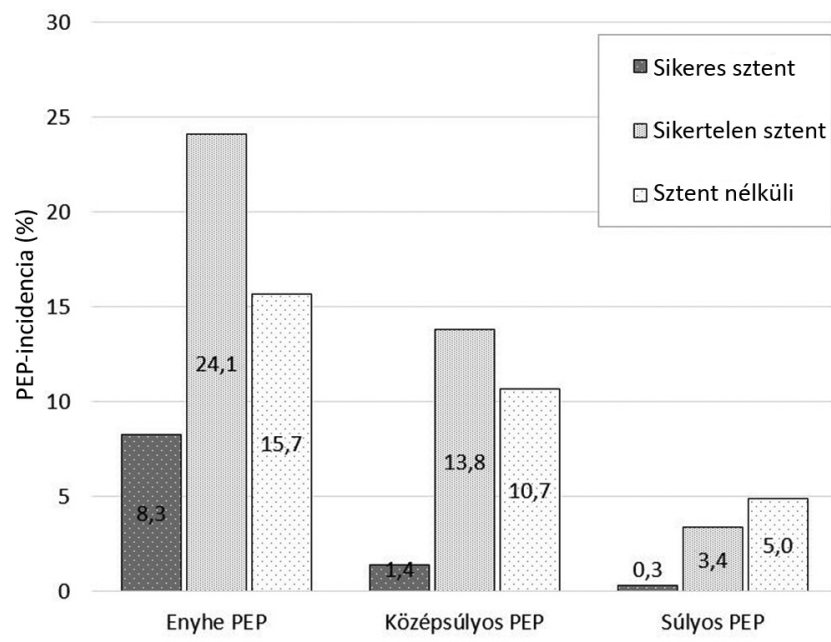

3. ábra $\mid$ A post-ERCP-pancreatitis különböző súlyossági formáinak incidenciája az egyes csoportokban. Jelen vizsgálatunk legfontosabb üzenete, hogy a magas rizikójú PEP-betegcsoportban a sikeres PPS-behelyezés hatására a súlyos, életet veszélyeztető PEP incidenciája 94\%-kal csökkenthető a sztent nélküli csoporthoz képest

ERCP = endoszkópos retrográd cholangiopancreatographia; PEP $=$ ERCP-t követő pancreatitis

nem volt sikeres („sikertelen sztent” csoport). A „sztent nélküli retrospektív kohorsz" csoportban 121, magas PEP-kockázatú, életkorban, nemben és rizikótényezőkben hasonló, ERCP-vizsgálaton átesett beteg adatait dolgoztuk fel. A PEP-kockázat minden csoportban öszszehasonlítható volt szignifikáns eltérés nélkül (2. táblázat).

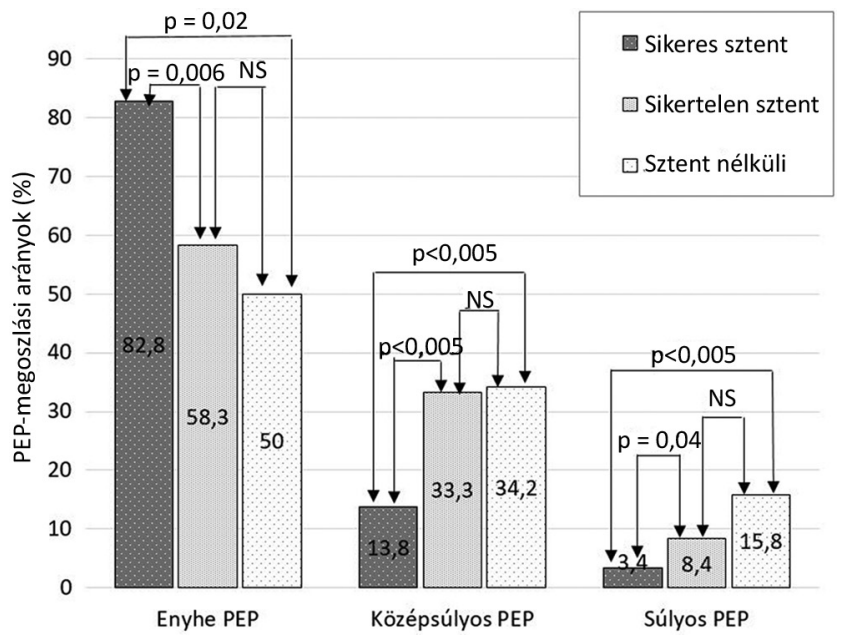

4. ábra $\quad$ A post-ERCP-pancreatitis megoszlási arányainak összehasonlítása. A sikeres PEP alkalmazásával a középsúlyos és a súlyos PEP előfordulási aránya is szignifikánsan és jelentős mértékben csökkenthető a PPS nélküli csoporttal összehasonlítva

ERCP = endoszkópos retrográd cholangiopancreatographia; $\mathrm{NS}=$ nem szignifikáns; PEP $=$ ERCP-t követő pancreatitis; $\mathrm{PPS}=$ profilaktikus pancreassztent

PEP kialakulását észleltük 29 betegnél a „sikeres sztent”, 12 betegnél a „sikertelen sztent” és 38 betegnél a „sztent nélküli” csoportban, ami az esetek 10,0\%, $41,3 \%$ és 31,4\%-át jelenti a fenti sorrendben. A „sikeres sztent" csoportban észlelt PEP-incidencia szignifikánsan alacsonyabb volt, mint a másik két csoportban $(\mathrm{p}<0,005)$, míg az utóbbi kettő esetében a különbség nem volt szignifikáns $(\mathrm{p}=0,3)$ (2. ábra).

A PEP súlyosságát illetően megfigyelhető, hogy mivel a PEP előfordulása is alacsonyabb, a különböző súlyossági csoportokba tartozó pancreatitisek incidenciája is kisebb a „sikeres sztent” csoportban, mint a másik két csoportban (3. ábra). Ha azonban a különböző súlyosságú eseteket az összes PEP arányában fejezzük ki, akkor megállapítható, hogy PPS alkalmazása mellett szignifikánsan alacsonyabb a középsúlyos és súlyos PEP aránya: ekkor a sztentnek köszönhetően döntően enyhe lefolyást mutat ez a szövődmény, szemben a „sikertelen sztent” és a „sztent nélküli” csoporttal (4. ábra). Az utóbbi két csoportban előforduló, különböző súlyosságú PEP-ek közötti különbségek nem szignifikánsak.

\section{A PPS-ekkel kapcsolatos szövődmények}

A sztentek használata során korai kicsúszást és proximalis sztentmigrációt észleltünk, de egyéb, az irodalomban publikált szövődmény saját anyagunkban nem fordult elő.

Magas kockázatú betegek esetében elfogadott nézet, hogy minimum 24 órán, de maximum 1 héten át kell a PPS-nek a helyén maradnia, hogy előnyös hatását láthassuk. Anyagunkban a 288, sikeresen sztentelt beteg közül összesen 5-nél láttunk korai kicsúszást (1,74\%), melyre a 
késői kezdetû akut PEP hívta fel a figyelmet. Minden ilyen beteg az ERCP-t követő első 8-12 órában panaszmentes volt, az első amiláz-ellenőrzés is a normáltartományon belüli volt, majd később hasi fájdalom alakult ki, és a másnap reggeli amilázérték is megemelkedett. A sztent pozícióját röntgenátvilágítással, szükség esetén gasztroszkópiával/duodenoszkópiával ellenőriztük, de azt nem találtuk a helyén. Az ötből 2 sztent BNS, a másik 3 viszont FS volt. Az egyetlen belső füllel bíró FSeknél l esetben a sztentet postpapillotomiás vérzés sodorta ki, a másik 2 betegnél pedig az index-ERCP során a papillának az epeúti kőextrakció előtt végzett ballonos tágítása játszhatott szerepet az idő előtti kicsúszásban. Minden esetben enyhe lefolyású volt a PEP.

Proximalis sztentmigráció esetén definíció szerint a sztent felcsúszik a Wirsung-vezetékbe, és a külső vége sem látható az orificiumban. Anyagunkban 3 betegben észleltünk ilyen szövődményt (1,04\%). Mindhárom esetben kettős belső és kettős külső füllel rendelkező, egyenes pancreassztentekről volt szó (BFS), melyek ráadásul 2 esetben egy hónapon túl voltak pozícióban, mivel a betegek nem jelentek meg a PPS-extrakcióra előjegyzett vizsgálatukon. A harmadik betegnél 6 napig volt bent a sztent, bár ez a beteg OSD-ben szenvedett, amely az irodalmi adatok alapján a proximalis migráció egyik rizikótényezője, a gyakori retrográd Oddi-sphincter fázikus kontrakciós tevékenység előfordulása miatt [10]. A 3-ból 2 betegnél pancreaticus sphincterotomiát követően sikeresen eltávolíthatók voltak a migrált sztentek. Náluk az

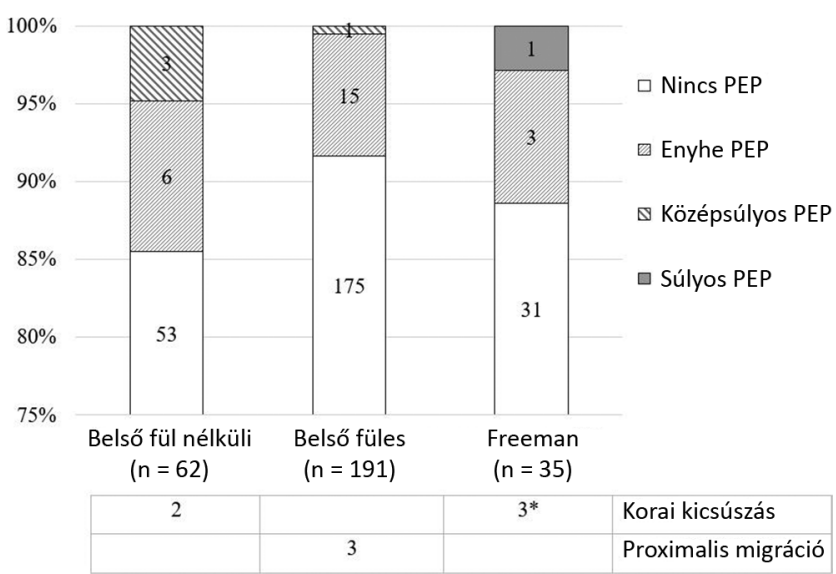

5. ábra

A post-ERCP-pancreatitis megoszlása a különböző sztenttípusok esetén. A különböző profilaktikus pancreassztentek preventív hatékonysága között a relatíve kis esetszám miatt nem tudtunk szignifikáns különbséget igazolni, azonban relatíve a legkevesebb PEP-szövődmény a belső füllel rendelkező betegcsoportban fordult elő, ez gátolja a korai sztentkicsúszást is Ezért jelenlegi gyakorlatunkban a belső füllel és külső „pigtail” véggel (a proximalis migráció is kizárt) rendelkező Freeman-tí pusú PPS-eket alkalmazzuk elószeretettel

ERCP = endoszkópos retrográd cholangiopancreatographia PEP = ERCP-t követő pancreatitis; PPS = profilaktikus pancreassztent

*Korai, idő előtti kicsúszásra hajlamosító egyéb tényező, illetve szövődmény minden esetben jelen volt. eltávolítást követően egy megfeleló pozícióba helyezett PPS mellett nem alakult ki PEP. Egy beteg esetében többszörös, sikertelen eltávolítási kísérlet után (melyek közül egy esetben enyhe PEP zajlott) végül sebészi megoldáshoz folyamodtunk, sikeres distalis pancreasreszekcióra került sor.

A különböző sztenttípusok összehasonlító elemzésekor azt észleltük, hogy hatékonyságuk nem különbözik szignifikánsan, de korai kicsúszás BNS-eknél, proximalis migráció pedig BFS-eknél fordult elő elsősorban, bár a szövődmények alacsony előfordulása miatt statisztikai számításokat végezni nem lehetett (5. ábra).

\section{Megbeszélés}

A PPS-ek szerepét a PEP megelőzésében az 1990-es évek közepétől kezdték intenzíven vizsgálni, kezdetben fóleg OSD miatt ERCP-n és sphincterotomián átesett betegek esetében, később, a rizikófaktorok alaposabb feltérképezése után, már a többi magas kockázatú betegpopulációban is. Minden prospektív vizsgálat a PEP incidenciájának csökkenését igazolta a sztentelt csoportban, sőt az 1999-től lefolytatott vizsgálatok statisztikailag szignifikáns különbséget igazolnak [11].

Munkacsoportunk több mint 10 éves tapasztalattal rendelkezik a PPS-ek implantációjában. Ezen időszak alatt nagyszámú, kis kaliberú pancreassztentelést végeztünk, és tapasztalataink, illetve jelen eredményeink egybevágnak az irodalmi adatokkal. Saját hazai anyagunkban, a magas kockázatú betegcsoportban a PPS szignifikánsan csökkentette a PEP kialakulásának valószínúségét. Ezt a tényt számos nemzetközi, randomizált prospektív tanulmány és metaanalízis is igazolta [12, 13]. Ami azonban még hangsúlyosabb előnyt jelent a szakirodalom alapján (még az NSAID alkalmazásával szemben is), az az, hogy a PPS a középsúlyos és a súlyos PEP előfordulási esélyét csökkenti a leginkább, tehát a PEP, amennyiben kialakul, enyhébb lefolyású a PPS alkalmazása mellett. A középsúlyos és a súlyos pancreatitis szignifikánsan alacsonyabb mértékben fordult elő saját anyagunkban is a PPS használata mellett, míg a sztent nélküli és a sikertelenül sztentelt betegeink adatai között nem volt szignifikáns különbség sem az incidenciában, sem a súlyossági csoportok megoszlásában.

Mindenképpen fel kell hívnunk azonban a figyelmet a sztenteléssel járó kockázatokra is. Ezek közül kiemelhető a sikertelen PPS-implantáció, melynek esetében a PEPincidencia még annál is magasabb lehet, mint ha meg sem kíséreltük volna behelyezni a sztentet [14]. Saját anyagunkban ez az érték a gyakran emlegetett Freemantanulmányhoz képest alacsonyabb volt ugyan, de még így is jelentős. Ezekben az esetekben az elhúzódó sikertelen pancreasvezeték-kanülálás, a nem megfelelően felhelyezett pancreas-vezetődrót hurkolódása vagy kicsúszása, pancreasdivisum vagy pancreasvezeték „kinking ”, papilla adenoma/tumor vagy vérzés és a nem megfelelő kaliberü pancreassztent alkalmazása játszhat szerepet a 
sikertelenségben. Megállapítható tehát, hogy a PPSimplantáció, bár technikailag nem tünik bonyolult beavatkozásnak, nagy tapasztalatú, operatív pancreasERCP-ben is jártas endoszkópos szakembert és csapatot igényel, hiszen a sikertelen pancreassztentelés veszélyét minimalizálni kell. Célszerú tehát a profilaktikus sztentelésben gyakorlatot szerezni. Az epeúti sztentelésben megszerzett jártasság nem jelenti egyúttal a pancreassztenteléshez szükséges gyakorlatot. A profilaktikus sztentelés során magas kockázatú betegekkel dolgozunk, más eszközöket (vékonyabb vezetődrót, puhább és vékonyabb sztentek), más technikát alkalmazunk, maga a vezeték anatómiája is más, elágazó, kisebb átmérőjü, sokszor rendkívül kanyargós lefutású, és gyakori az ún. „kinking” anatómiai variáns előfordulása. Saját gyakorlatunkból és eredményeinkből kiindulva a magas kockázatú betegpopulációban javasoljuk a PPS-ek használatát, ehhez azonban az ERCP-s endoszkópos szakemberek megfelelő edukációját is szükségesnek tartjuk.

A mindennapi gyakorlatban korai, idő előtti sztentkicsúszásra érdemes gondolni, ha az ERCP utáni panaszmentes időszakot követően, a vizsgálat után 8-12 órával alakul ki PEP. Egy korábbi, túpapillotomiás randomizált vizsgálatban amerikai szerzők kimutatták, hogy idő előtt eltávolított PPS esetén magasabb a PEP-arány, mint ha sztentelés nem is történik [15]. A korai sztentkicsúszás kivédésére saját eredményeink alapján hasznosnak tünik a belső füllel rendelkező sztent használata (a belső fülnek atraumatikusnak kell lennie), habár a sztent későbbi eltávolítása a beteg számára egy újabb endoszkópos vizsgálatot jelent. Ez utóbbi miatt a nemzetközi szakirodalom, elsősorban költséghatékonysági megfontolásokat figyelembe véve, előnyben részesíti a belső fülekkel nem rendelkező PPS-ek alkalmazását. A belső füles sztentek esetében azonban fontos figyelni arra, hogy csak egyetlen belső füle legyen, ugyanis a kettős belső fül (az OSD és a hosszú méret mellett) a proximalis migráció rizikótényezője, melynek komoly következményei lehetnek [16].

Saját gyakorlatunkban a különböző típusú sztentek használatával szerzett tapasztalataink alapján a proximalis migrációnak mint potenciálisan súlyos szövődménynek az elkerülésére a legoptimálisabbnak az FS-eket tartjuk. Ezeknél egyetlen belső fül és egy külső, részleges „pigtail” vég látható. A sztent ilyen kiképzése egyrészt az idő előtti kicsúszást is meg tudja akadályozni, melyet belső fül nélküli sztentek esetén tapasztaltunk (vagy egyéb szövődmény kapcsán), másrészt a proximalis migrációt is megakadályozza, melyet csak a kettős belső füllel bíró egyenes sztenteknél láttunk. Szintén nagyon fontos, hogy minden esetben endoszkóposan távolítsuk el a PPS-eket 5-7 napon belül. Az ilyen rövid időn belül eltávolított sztentek esetén sem pancreatitist, sem vezetékkárosodást, sem proximalis migrációt nem tapasztaltunk $[17,18]$.

A PPS-ek alkalmazása mellett természetesen a szakirodalmi eredményekkel megegyezően javasoljuk - és saját gyakorlatunkban jelenleg az ESGE-ajánlásnak megfele- lően minden ERCP-re kerülő betegben, amennyiben nincs ellenjavallat, használjuk is - az egyéb, PEP-megelőző technikákat, így a Ringer-laktáttal végzett megfelelő hidrációt és az NSAID-kúpokat is.

\section{Következtetés}

Elmondhatjuk, hogy megfelelő gyakorlattal és körültekintéssel a magas kockázatú betegpopulációban alkalmazott profilaktikus pancreassztentelés a PEP incidenciáját is szignifikánsan csökkenti, de jelentős mértékben javítja a pancreatitises szövődmény lefolyását is, mivel a súlyosságát az enyhébb esetek felé tolja el. Használata során a megfelelő endoszkópos technika mellett az optimális sztentválasztás és a sztentek megfelelő időben történő eltávolítása is lényeges szempont. Amennyiben ezeket az elővigyázatossági intézkedéseket betartjuk, jelentősen javíthatjuk a magas kockázatú betegpopuláció ERCP-vel járó szövődményeinek iatrogén kockázatát, és kedvezőbb kimenetelt, illetve teljes gyógyulást biztosíthatunk számukra.

Anyagi támogatás: A jelen kutatómunka és a közlemény megírása anyagi támogatásban nem részesült.

Szerzői munkamegosztás: D. Zs., H. I., Sz. A., M. L.: A vizsgálatok elvégzése, adatgyüjtés. D. Zs.: A kézirat elkészítése. H. I., M. L.: A kézirat javítása. A cikk végleges változatát valamennyi szerző elolvasta és jóváhagyta.

Érdekeltségek: A szerzőknek nincsenek érdekeltségeik.

\section{Irodalom}

[1] Kochar B, Akshintala VS, Afghani E, et al. Incidence, severity, and mortality of post-ERCP pancreatitis: a systematic review by using randomized, controlled trials. Gastrointest Endosc. 2015; 81: 143-149.e9.

[2] Dumonceau JM, Kapral C, Aabakken L, et al. ERCP-related adverse events: European Society of Gastrointestinal Endoscopy (ESGE) guideline. Endoscopy 2020; 52: 127-149.

[3] Freeman ML, DiSario JA, Nelson DB, et al. Risk factors for postERCP pancreatitis: a prospective, multicenter study. Gastrointest Endosc. 2001; 54: 425-434.

[4] Woods KE, Willingham FF. Endoscopic retrograde cholangiopancreatography associated pancreatitis: a 15-year review. World J Gastrointest Endosc. 2010; 16: 165-178.

[5] Freeman ML, Guda NM. Prevention of post-ERCP pancreatitis: a comprehensive review. Gastrointest Endosc. 2004; 59: 845864.

[6] Andriulli A, Forlano R, Napolitano G, et al. Pancreatic duct stents in the prophylaxis of pancreatic damage after endoscopic retrograde cholangiopancreatography: a systematic analysis of benefits and associated risks. Digestion 2007; 75: 156-163.

[7] Dubravcsik Z, Hritz I, Szepes A, et al. Risk factors of post-ERCP pancreatitis in high-risk patients despite prevention with prophylactic pancreatic stents. Scand J Gastroenterol. 2020; 55: 95-99.

[8] Dumonceau JM, Andriulli A, Deviere J, et al. European Society of Gastrointestinal Endoscopy (ESGE) guideline: prophylaxis of post-ERCP pancreatitis. Endoscopy 2010; 42: 503-515. 
[9] Cotton PB, Lehman G, Vennes J, et al. Endoscopic sphincterotomy complications and their management: an attempt at consensus. Gastrointest Endosc. 1991; 37: 383-393.

[10] Johanson JF, Schmalz MJ, Geenen JE. Incidence and risk factors for biliary and pancreatic stent migration. Gastrointest Endosc. 1992; 38: 341-346.

[11] Freeman ML. Pancreatic stents for prevention of post-ERCP pancreatitis: for everyday practice or for experts only? Gastrointest Endosc. 2010; 71: 940-944.

[12] Mazaki T, Mado K, Masuda H, et al. Prophylactic pancreatic stent placement and post-ERCP pancreatitis: an updated metaanalysis. J Gastroenterol. 2014; 49: 343-355.

[13] Choudhary A, Bechtold ML, Arif M, et al. Pancreatic stents for prophylaxis against post-ERCP pancreatitis: a meta-analysis and systematic review. Gastrointest Endosc. 2011; 73: 275-282.

[14] Freeman ML, Overby C, Qi D. Pancreatic stent insertion: consequences of failure and results of a modified technique to maximize success. Gastrointest Endosc. 2004; 59: 8-14.
[15] Cha SW, Leung WD, Lehman GA, et al. Does leaving a main pancreatic duct stent in place reduce the incidence of precut biliary sphincterotomy-associated pancreatitis? A randomized, prospective study. Gastrointest Endosc. 2013; 77: 209-216.

[16] Freeman ML. Pancreatic stents for prevention of post-endoscopic retrograde cholangiopancreatography pancreatitis. Clin Gastroenterol Hepatol. 2007; 5: 1354-1365.

[17] Moffatt DC, Coté GA, Fogel EL, et al. Acute pancreatitis after removal of retained prophylactic pancreatic stents. Gastrointest Endosc. 2011; 73: 980-986.

[18] Hritz I, Dubravcsik Z, Szepes A, et al. Does removal of prophylactic pancreatic stents induce acute pancreatitis? Gastrointest Endosc. 2011; 74: 1429-1430.

(Dubravcsik Zsolt dr., Kecskemét, Nyíri út 38., 6000 e-mail: dubravcsikzs@kmk.hu)

\section{PÁLYÁZAT}

A Prof. Dr. Romics László Akadémikus Emlékére Alapítvány pályázatot hirdet Magyarországon dolgozó, magyar állampolgárságú, 40 éven aluli orvosok és orvosbiológiai kutatással foglalkozó személyek számára. A nyertes pályázó(k) között 500000 Ft alapítványi adomány kerül kiosztásra.

A pályázat célja: a klinikai gyógyítás vagy orvosi tudományos kutatás területén dolgozók kiemelkedő tudományos tevékenységének elismerése.

Előnyt élveznek azok a pályázók, akik az alapítvány névadójának munkásságát folytatva cardiovascularis és anyagcsere-betegségek területéről nyújtanak be pályázatot.

A pályázat benyújtásának határideje: 2021. február 28. (elbírálásának határideje: 2021. április 30.)

A pályázatot a palyazat@romicsalapitvany.hu e-mail címre pdf formátumban kell benyújtani.

A pályázatot természetes személy, saját nevében, magyar nyelven nyújthatja be, a pályázati anyag ábrák nélkül maximum 15000 leütés (karakter) terjedelmü lehet. A pályázathoz mellékelni kell egy rövid szakmai életrajzot a születési év megjelölésével.

A pályázat benyújtását saját kézzel aláírt és dátummal ellátott levélben kell bejelenteni az alapítvány titkárának címezve (a borítékra írandó cím: dr. Dudás Márta, 1461 Budapest, Pf. 62) könyvelt (ajánlott) küldeményben, mert ezen bejelentés alapján válik hitelessé a pályázat. A pályázatot nyomtatott formában nem kell mellékelni.

Az alapítvány adatairól, működéséről a www.romicsalapitvany.hu honlapon található információ. 